\title{
The Development of Local Cultural Based Interactive Instructional Media in Learning English
}

\author{
Nazlia \\ Educational Technology, Postgraduate Program \\ Universitas Negeri Medan \\ Medan, Indonesia \\ nazlia.iara@gmail.com
}

\author{
Julaga Situmorang \\ Educational Technology \\ Universitas Negeri Medan \\ Medan, Indonesia
}

\begin{abstract}
The local cultural based interactive instructional media was developed to teach students in learning English independently with the content, exercise and evaluation connected to the local culture. This study aims to produce a proper local cultural based interactive instructional media and to know the effectiveness of the media. This study belongs to a research and development which uses the $R \& D$ model by Borg and Gall and combined with the instructional design model by Dick and Carey. The result of the validation and trial process shows that the developed interactive instructional media is in the criteria of very good. This result indicates that the media is proper to use in learning English. In the phase of effectiveness testing with quasi experimental method, the result shows that the local cultural based interactive instructional media is effective to improve the English learning outcome of students. The result of hypothesis testing indicates that there is a significant difference between the English learning outcome of students which were taught with a local cultural based interactive instructional media and the students which were taught with a presentation media Power Point. Therefore, the local cultural based interactive instructional media is proper and effective used in learning English.
\end{abstract}

Keywords- interactive instructional media, local culture, english

\section{INTRODUCTION}

English is a communication tool both in writing or speaking which is used globally. English is a moving spirit of globalization era in science, technology, politic, social culture and economic. Learning English as foreign language is also an essential thing for many countries in the world, especially for the developed countries like Indonesia. Indonesian government through their Education and Culture Ministry established English as an obliged subject which is involved in National Examination for Junior and Senior High School. The purpose is to build human resources with competitive character in the global era.

Technology always gets better development day by day and it affects the development in education. The education experts try to integrate the sophisticated technology in education system. The teachers as the agent of instructional process must be able to use technology in order to create an innovative instruction. The innovative instruction can be applied by providing the variety of instructional media, such as audio, video, audio visual or multimedia. Multimedia technology can facilitate the education process through tools which can improve the interaction among teacher, students and instructional media in innovative ways in order to make the instructional process be more dynamic and applicable [1]. Then, the instructional process with multimedia is a modern instruction that can support the learning activity and interaction [2].

Curriculum of 2013 also emphasizes a few things related to an innovative instruction. They are: (1) students centered learning, (2) interactive learning (interaction among students, teacher, society, environment and any other sources/media), (3) network learning (students can get knowledge from anybody and anywhere or even from internet), (4) active finding learning, (5) cooperative learning, (6) multimedia based learning, (7) users' need based learning by developing a special skill that the students have, (8) multidiscipline learning, and (9) critical learning.

Based on the curriculum of 2013, instruction is designed to give an experience in using English texts to understand and apply the factual, conceptual, and procedural knowledge which is related to the visible phenomenon and event through speaking, listening, reading and writing. Therefore, in learning English there are four skills as its objective. They are speaking, listening, reading and writing. Curriculum of 2013 uses scientific learning, so students are expected to be active in the instructional process through watching, questioning, exploring, associating and communicating in order to reach the learning objectives. Those activities can be created through an innovative instruction with multimedia based interactive learning. Technology has benefits in cognitive area as it can improve teachers' quality in teaching, make the instructional delivery process runs more efficiently, explain the learning concept more clearly, and improve the interaction among students [3]. In addition, media in learning is a bridge which connects the theory and practice [4]. Related to English learning, introducing innovative learning materials like advertisement in a newspaper, sport news, film, tourism brochure and other authentic materials can grow students' curiosity and they can be used to transfer the language skill without difficulty [5]. Those statements emphasize that the use of innovative instructional media like multimedia can improve the effectiveness of instructional process. Then, to create a meaningful instruction in using multimedia, students must involve five cognitive process such as: (1) choosing the 
relevant words to process verbal information; (2) choosing the relevant picture to process visual information; (3) managing the chosen words into verbal model; (4) managing the chosen picture into pictorial model; and (5) integrating the verbal and pictorial information with entry behavior [6].

In this technology era, there are many schools still using conventional method in the instructional process. An observation was done in Senior High School of Harapan Mekar Medan and it was found that they still use conventional instructional media like text book and students' work sheet. In learning English, the teacher uses presentation media of Power Point at any times, but the use is not maximal. Then, the students consider English as a difficult subject because it is a foreign language. It is caused by the delivery system in which the material in the text book is difficult to be understood by the students. The explanation and examples given in the text book are not connected directly to the students' daily life. Those problems causes the students' interest in learning English is bad. It gives influence to the students' mark which is under the passing grade. Therefore, teachers must be able to create an innovative instruction by integrating technology in it. Technology based instruction must be able to attract students' interest because in the global era, students are very close to the technology such as computer, laptop and smartphone. They also prefer visual things.

Besides that, in curriculum of 2013, the national culture must be learnt to create the sense of pride to the students' self. Therefore, the national cultures as the identity of Indonesia must be learnt at school by integrating it to every subject. Learning character based on the local culture of Medan can build the national character values in students such as religious, honest, tolerant, discipline, work-hard, creative, independent, democratic and others [7].

Culture is the whole idea system owned by people in learning [8]. Cultural based instruction is a strategy to create learning environment and design learning experience which integrates culture as a part of the instructional process [9]. Local culture is a custom, a developed culture or a habit in a certain area [10]. So, local cultural based instruction is an instruction which integrates the cultural elements from a certain area, like Deli Malay Culture as a typical culture of Medan. The purpose of education is not only to educate people with good information, but also to learn culture as well as the knowledge [11]. Based on that statement, the integration of local cultural based instruction in learning English can be applied.

Therefore, the best solution of the problems found in Senior High School of Harapan Mekar Medan is to develop a local cultural based interactive instructional media in learning English. The local culture which will be integrated in the instructional media was exist on the reading text, supported examples and exercises. The presentation of the matter is completed by audio, text and video in order to create an interactive instructional multimedia. A researcher said that multimedia is really helpful for teacher in teaching and creating an interactive instruction [12]. Then, another researcher said that in culture based instruction, learning environment will be changed to be a pleasant one for teacher and students that enables teacher and students to take part actively based on the culture they have known so they can get an optimal learning outcome [13].

Based on the description above, the objectives of this study are: (1) to develop a proper local cultural based instructional media in learning English; and (2) to test the effectiveness of the local cultural based instructional media in learning English which is compared to the use of presentation media Power Point.

\section{RESEARCH METHOD}

The method used in this study is research and development which uses R\&D model by Borg and Gall [14] and combined with instructional design model by Dick and Carey [15]. This research was conducted in Senior High School of Harapan Mekar Medan. The subject of this research is the tenth graders of the school.

There are five steps to produce this local cultural based interactive instructional media in learning English. They are: (1) preliminary, it involved some activities, such as identifying instructional goal, conducting instructional analysis, analyzing learners and context, writing performance objectives, developing assessment instrument, developing instructional strategy, developing and selecting instructional materials; (2) planning, it was done by making manuscript, schema of the media, storyboard and then collecting the instructional material and picture, recording and creating the audio/video; (3) development, it was done by completing the media with learning guidance, basic competence, content, exercise, summary, evaluation, feedback and closing; (4) validation, the media was validated by content experts, instructional design experts, and instructional media experts. The product is revised based on their assessment, critic and suggestion; (5) trial test, it included individual trial test, small group trial test and field trial test. The assessment of the trial test was analyzed to do the next revision toward the product.

The data was analyzed by using quantitative descriptive analysis. The data was analyzed by using descriptive statistic technique. The qualitative data such as "Very Poor", "Poor", "Enough", "Good" and "Very Good" was changed into quantitative data in the scale of 1 to 5 . The criteria of the media was converted based on Likert Scale and it was analyzed by using the pattern below:

$$
X=\frac{\text { I otal Score }}{\text { Ideal Total Score }} \times 100 \%
$$

The criteria of the assessment can be seen in Table I.

TABLE I. THE CRITERIA OF ASSESSMENT

\begin{tabular}{|c|c|}
\hline Percentage & Criteria \\
\hline $85-100$ & Very Good (Very Proper) \\
\hline $75-84$ & Good (Proper) \\
\hline $65-74$ & Enough (Proper Enough) \\
\hline $55-64$ & Poor (Improper) \\
\hline $0-54$ & Very Poor (Very Improper) \\
\hline
\end{tabular}

Then, the research was continued to the effectiveness test of the product. The effectiveness test toward the product was 
conducted in two classes as fllows: (1) the class which was taught by using the local cultural based interactive instructional media as the experimental class with 32 students; and (2) the class which was taught by using the presentation media Power point as the controlled class with 30 students. The hypothesis was tested by using two way t-test with the pattern as follows:

$$
\tau=\frac{\overline{x_{1}-\bar{x}_{2}}}{\sqrt[3]{\frac{1}{m_{1}}+\frac{3}{B_{2}}}} \quad \text { Reference [16] }
$$

The test could be conducted if the data could pass some requisite tests as follow: (1) data normality test by using Liliefors technique, and (2) data homogeneity test by using Fisher test. The pattern of Liliefors technique is:

$$
\mathrm{L}_{0}=\mathrm{F}(\mathrm{zi})-\mathrm{S}(\mathrm{zi})
$$

Then, the pattern of Fisher test is:

$$
\mathrm{F}=\frac{\text { The Biggest Variance }}{\text { The Smallest Variance }}
$$

The hypothesis in conducting the effectiveness test of the product can be seen as follows:

$\mathrm{H}_{0}=$ there is no difference between the English learning outcome of students who are taught by using local cultural based interactive instructional media with the ones who are taught by using presentation media Power Point.

$\mathrm{H}_{\mathrm{a}}=$ there is difference between the English learning outcome of students who are taught by using local cultural based interactive instructional media with the ones who are taught by using presentation media Power Point.

$\mathrm{H}_{0}$ is accepted and $\mathrm{H}_{\mathrm{a}}$ is rejected if the value of $\mathrm{t}$ is lower than the value of $t$ in the table $\left(t_{\text {table }}\right)$. On the other hand, $H_{0}$ is rejected and $\mathrm{H}_{\mathrm{a}}$ is accepted if the value of $\mathrm{t}$ is higher than the value of $\mathrm{t}$ in the table $\left(\mathrm{t}_{\text {table }}\right)$ at the significance level of 0.05 .

\section{RESULT AND DISCUSSION}

Based on the objectives of this study, there are two main points as the result of this research. They are: (1) the result of validity and trial toward the local cultural based interactive instructional media in learning English, and (2) the result of the effectiveness test toward the local cultural based interactive instructional media in learning English.

\section{A. The Validity of the Product}

The local cultural based interactive instructional media in learning English which was developed in this research was validated by 6 experts. They are 2 English content experts, 2 instructional design experts and 2 instructional media experts. After the validity of the experts, the product must get trial test to the users (students) with the specification as follows: 3 students in individual trial, 9 students in small group trial and 32 students in limited field trial.

The result of English content experts toward the local cultural based interactive instructional media is very good with the percentage of $92.31 \%$. The detail assessment can be seen in Table II.

TABLE II. THE ASSESSMENT OF CONTENT EXPERTS

\begin{tabular}{|c|c|c|}
\hline \multicolumn{1}{|c|}{ Indicator } & Percentage & Criteria \\
\hline Guidance and information & $90 \%$ & Very Good \\
\hline Content of media & $91.54 \%$ & Very Good \\
\hline Evaluation & $95 \%$ & Very Good \\
\hline Total & $\mathbf{9 2 . 3 1 \%}$ & Very Good \\
\hline
\end{tabular}

The result of instructional design experts toward the local cultural based interactive instructional media is also very good with the percentage of $88.57 \%$. The detail assessment can be seen in Table III.

TABLE III. The Assessment of Instructional Design ExPERTS

\begin{tabular}{|l|c|c|}
\hline \multicolumn{1}{|c|}{ Indicator } & Percentage & Criteria \\
\hline Content Expedience & $90 \%$ & Very Good \\
\hline Presentation & $88 \%$ & Very Good \\
\hline Graphic & $88.57 \%$ & Very Good \\
\hline \multicolumn{1}{|c|}{ Total } & $\mathbf{8 8 . 5 7 \%}$ & Very Good \\
\hline
\end{tabular}

The result of instructional media experts toward the local cultural based interactive instructional media is also very good with the percentage of $86.84 \%$. The detail assessment can be seen in Table IV.

TABLE IV. THE ASSESSMENT OF MEDIA EXPERTS

\begin{tabular}{|c|c|c|}
\hline \multicolumn{1}{|c|}{ Indicator } & Percentage & Criteria \\
\hline Guidance and information & $93.33 \%$ & Very Good \\
\hline Software operation & $82 \%$ & Very Good \\
\hline Evaluation & $88 \%$ & Very Good \\
\hline Total & $\mathbf{8 6 . 8 4 \%}$ & Very Good \\
\hline
\end{tabular}

Then, in the individual trial, the local cultural based interactive instructional media got the percentage of $91.48 \%$ in the criteria of very good. The detail result can be seen in Table V.

TABLE V. THE ASSESSMENT OF INDIVIDUAL TRIAL

\begin{tabular}{|l|c|c|}
\hline \multicolumn{1}{|c|}{ Indicator } & Percentage & Criteria \\
\hline Guidance and information & $85 \%$ & Very Good \\
\hline Content of media & $88.21 \%$ & Very Good \\
\hline Evaluation & $92 \%$ & Very Good \\
\hline Design and facilities of media & $96.30 \%$ & Very Good \\
\hline Pedagogic effect & $96 \%$ & Very Good \\
\hline \multicolumn{1}{|c|}{ Total } & $\mathbf{9 1 . 4 8 \%}$ & Very Good \\
\hline
\end{tabular}

In the small group trial, the local cultural based interactive instructional media got the percentage of $94.94 \%$ in the criteria of very good too. The detail result can be seen in

\begin{tabular}{|c|c|c|}
\hline Indicator & Percentage & Criteria \\
\hline Guidance and information & $92.22 \%$ & Very Good \\
\hline Content of media & $95.73 \%$ & Very Good \\
\hline Evaluation & $95.56 \%$ & Very Good \\
\hline Design and facilities of media & $94.81 \%$ & Very Good \\
\hline Pedagogic effect & $94.67 \%$ & Very Good \\
\hline Total & $94.94 \%$ & Very Good \\
\hline
\end{tabular}
Table VI.

TABLE VI. The Assessment of SMALl Group Trial 
The last one is the field trial, the local cultural based interactive instructional media got the percentage of $92.80 \%$ which is also in the criteria of very good. The detail assessment can be seen in Table VII.

TABLE VII. ThE ASSESSMENT OF FIELD TRIAL

\begin{tabular}{|l|c|c|}
\hline \multicolumn{1}{|c|}{ Indicator } & Percentage & Criteria \\
\hline Guidance and information & $93.13 \%$ & Very Good \\
\hline Content of media & $92.07 \%$ & Very Good \\
\hline Evaluation & $93.13 \%$ & Very Good \\
\hline Design and facilities of media & $93.33 \%$ & Very Good \\
\hline Pedagogic effect & $93.13 \%$ & Very Good \\
\hline \multicolumn{1}{|c|}{ Total } & $\mathbf{9 2 . 8 0 \%}$ & Very Good \\
\hline
\end{tabular}

The result of validity from the experts indicated that the local cultural based interactive instructional media is very proper to be used as a media in learning English especially in the competence of descriptive text. The media has fulfilled the standard of learning content, instructional design and instructional media. It is also appropriate with the characteristic of students as the users and it has fulfilled the students' need in learning.

Media contains of information and knowledge which is designed to facilitate the students in communicating and learning [17]. By using multimedia, the learning process turns to be objectives oriented learning and it is also more participative and flexible, so it can create self directed learning and improve the collaboration among students and teacher. Through multimedia, the learning information can be delivered in effecrive way because teacher can deliver the learning information in many kinds of media [1]. Another statement also said that the use of authentic instructional media can create the curiosity that can be used to transfer the language skill easily. The change of instructional media from text book to the interesting media can improve the students' motivation to master the language they learn [5]. Related to the cultural based learning in leraning English, it is said that the local or national culture is important to be integrated in instructional media of learning English as an effort to maintain the national culture in the era when the foreign culture like the western comes into the instructional process especially in learning the foreign language. Therefor, the local cultural based instructional media is effective to be used in learning English [18].

The statements above support the result of this validity and trial test toward the local cultural based interactive instructional media in which the media is proper to facilitate students in learning English independently or collaboratively.

\section{B. The Effectiveness of the Product}

The result of validity test toward the pre test data in the experimental class was obtained that $\mathrm{L}_{0}$ was lower than the value of Liliefors table $(0.102<0.157)$. In the controlled class was also obtained that $\mathrm{L}_{0}$ was lower than the value of Liliefors table $(0.088<0.161)$. Then, the result of validity test toward the post test data in the experimental class was obtained that $\mathrm{L}_{0}$ was lower than the value of Liliefors table $(0.139<0.157)$. In the controlled class was also obtained that $\mathrm{L}_{0}$ was lower than the value of Liliefors table $(0.107<0.161)$. In conclusion, the data of pre test and post test both in the experimental class and controlled class had normal distribution at the significance level of 0.05 .

The result of homogeneity test toward the pre test data in the experimental and controlled class was obtained that the value of $F$ was lower than the value of $F_{\text {table }}(1.16<1.89)$, so the data in both classes had the same variance or homogenous. Then, the homogeneity test toward the post test data in the experimental and controlled class was also obtained that the value of $F$ was lower than the value of $F_{\text {table }}(1.60<1.89)$, so it can be concluded that the data in both classes had the same variance or homogenous.

The research was continued to the hyphothesis testing because the data was normal and homogenous. The testing was conducted by using two way t-test. It was obtained that $\mathrm{t}=3.46$ and $\mathrm{t}_{\text {table }}=1.67$, so it means that $\mathrm{t}>\mathrm{t}_{\text {table }}$ at the significance level of 0.05 . Based on the result, it can be concluded that Ho was rejected meanwhile Ha was accepted. On the other words, there was a significant difference between the English learning outcome of students' who were taught by using the developed local cultural based interactive instructional media with the ones who were taught by using presentation media Power Point at the significance level of $5 \%$.

The effectiveness score of the developed local cultural based interactive instructional media is $83.56 \%$, whereas the effectiveness score of the presentation media Power Point is only $76.83 \%$. In conclusion, the local cultural based interactive instructional media is more effective to be used in learning English especially for the tenth graders of Senior High School than the presentation media Power Point.

The effectiveness of the local cultural based interactive instructional media was caused by one main factor which it can create self directed learning. The developed media can fulfill all the characteristics of instructional media used in self directed learning. The characteristics are: (a) self instructional (the media can be used independently by the students); (b) self-explanatory power (the media can explain by itself because it uses understandable language with systematic content); (c) self-paced learning (the students can learn the media based on their own ability without waiting the slow ones); (d) ) self-contained (the media is completed, so the students do not need to use another media); (e) individualized learning materials (the media is designed based on the students' need and characteristics); (f) flexibel and mobile learning materials (the media can be used by students wherever and whenever); (g) communicative and interactive learning materials (the media is designed based on the principal of effective communication and it involves the communication to the students); (h) multimedia, computerbased materials (the media is based on multimedia and the use of optimal computer); and (i) supported by tutorials, and study group (the media still needs the support of teacher and discussion group) [17]. 
The effectiveness of the the local cultural based interactive instructional media can support one statement that said the use of multimedia in learning English can improve the students' learning outcome [19]. Another statement said that the interactive multimedia is effective to improve students' pre test score to be better in the post test in learning English [20]. Related to the cultural based instructional, it is said that the cultural based learning strategy can affect students' learning outcome positively especially for the the local people who learn their own culture. In this case, the researcher focused on the Hawaiian culture, so the cultural based learning can improve the Hawaiian people's learning outcome [21].

Based on the statements above, it proves that the local cultural based interactive instructional media is effective to be used in learning English.

\section{CONCLUSION}

Based on the result and discussion of this study, it can be concluded that:

A. The local cultural based interactive instructional media in learning English for the tenth graders students has fulfilled the validity standard of instructional media and it is proper to be used as instructional media in learning English.

$B$. The use of the local cultural based interactive instructional media is effective to improve the students' English learning outcome. The product can attract the students' interest in learning English through the local cultural based learning. Then, the product can be used continuously in learning English especially for Senior High School students.

\section{ACKNOWLEDGMENT}

In this occasion the author expressed her appreciation and profound gratitude to the Headmaster, English teachers and students of Senior High School of Harapan Mekar Medan who have helped and supported the author in conducting this study.

\section{REFERENCES}

[1] Almara'beh, H., Amer, E. F., \& Sulieman, A. (2015). The Effectiveness of Multimedia Learning Tools in Education. International Journal of Advanced Research in Computer Science and Software Engineering, 5(12), 761-764

[2] Munir. (2015). The Use of Multimedia Learning Resource Sharing (MLRS) in Developing Sharing Knowledge at Schools. International Journal of Multimedia and Ubiquitous Engineering, 10(9), 61-68. doi: 10.14257/ijmue.2015.10.9.07

[3] Zhou, M., \& Teo, T. (2017). Exploring Student Voice in Teachers Motivation to Use ICT in Higher Education: Qualitative Evidence from a Developing Country. International Journal of Educational Technology, 4(1), 26-33.

[4] Benson, A., \& Odera, F. (2013). Selection and Use of Media in Teaching Kiswahili Language in Secondary Schools in Kenya. International Journal of Information and Communication Technology Research, 3(1), 12-18

[5] Rao, B. M. (2014). Use of Media as an Instructional Tool in English Language Teaching (ELT) at Undergraduate Level. International
Journal of English and Literature, 5(6), 141-143. doi: 10.5897/IJEL2014.0580

[6] Mayer, R. E. (2005). The Cambridge Handbook of Multimedia Learning. Santa Barbara: Cambridge University Press.

[7] Napitupulu, E., Panjaitan, K., \& Tambunan, H. (2017). National Character Building Through Manners Education Based on Regional Culture of North Sumatera. International Journal of Advanced Engineering, Management and Science (IJAEMS), 3(5), 568-575. doi: 10.24001/ijaems.3.5.27

[8] Koentjaraningrat. (2002). Pengantar Ilmu Antropologi. Jakarta: PT. Rineka Cipta.

[9] Sardjiyo \& Pannen, P. (2005). Pembelajaran Berbasis Budaya: Model Inovasi Pembelajaran dan Implementasi Kurikulum Berbasis Kompetensi. Jurnal Pendidikan, 6(2), 83-98

[10] Hermanto, I. (2010). Pintar Antropologi. Jakarta: Tunas Publishing.

[11] Mursid, R. (2016). Contribution of Educational Technology in the Development Constructivistic Learning Model Culture Based and Character. Conservation Education in the Era of Innovation and Technology: Prosiding dari the 2nd International Seminar on Educational Technology (ISET), Semarang, 25 Mei 2016 (pp. 440-450). Semarang: UNNES.

[12] Xiaowei, Z. (2015). The Design of Multimedia Interactive Courseware Based on FLASH. International Conference on Education, Management and Computing Technology, (pp. 1845-1849). Retrieved from http://www.atlantis-press.com/proceedings/icemct-15.

[13] Fahrurrozi, M. (2015). Pembelajaran Berbasis Budaya: Model Inovasi Pembelajaran dan Implementasi Kurikulum Berbasis Kompetensi. Seminar Nasional dan Call for Papers Pendidikan Karakter dalam Pembelajaran Bisnis dan Manajemen, (pp. 1-11). Malang: Universitas Negeri Malang.

[14] Gall, M. D., Gall, J. P., \& Borg, W. R. (2003). Educational Research: An Introduction (7th ed.). USA: Pearson Education, Inc.

[15] Dick, W., Carey, L., \& Carey, J. O. (2015). The Systemic Design of Instruction. USA: Pearson.

[16] Sudjana. (2005). Metoda Statistika. Bandung: Tarsito.

[17] Suparman, A. (2012). Desain Instruksional Modern. Jakarta: Erlangga.

[18] Sudartini, S., Sugirin, Suciati, \& Nurhayati, L. (2012). Pengembangan Buku Ajar Bahasa Inggris SMP Berbasis Multikultur sebagai Upaya Pemertahanan Budaya Lokal. Laporan Penelitian Unggulan UNY. Retrieved from http://eprints.uny.ac.id/25301.

[19] Dwihartanti, M., \& Gafur, A. (2015). Pengembangan Multimedia Pembelajaran Bahasa Inggris Kelas IV SD untuk Meningkatkan Hasil Belajar. Efisiensi, 13(1), 1-13. doi: 10.21831/efisiensi.v13i1.7857

[20] Romodon, D., Kusrini, \& Fatah, A. (2013). Rancang Bangun Model Pembelajaran Bahasa Inggris Interaktif Berbasis Multimedia. Jurnal Ilmiah Among Makarti, 6(11), 1-24.

[21] Kana'iaupuni, S., Ledward, B., \& Jensen, U. (2010). Culture-Based Education and Its Relationship to Student Outcomes. Kamehameha Schools Research \& Evaluation Division. Retrieved from http://www.ksbe.edu/_assests/spi/pdfs. 